\title{
Impact of Service Quality and Customer Satisfaction on Customer Loyalty: A Case Study in a Private Hospital in Indonesia
}

\author{
Jamaluddin $^{1}$, Endang Ruswanti ${ }^{2}$ \\ Magister Management Esa Unggul University Jakarta Indonesia
}

\begin{abstract}
It is necessary to consider the visit rate of outpatient in order to increase hospital revenue. Accordingly, to create customer satisfaction, a hospital should be able to improve its service quality. Therefore, dimensions of service quality as determinants of customer satisfaction for establishment of patient loyalty need to consider. The previous researches have confirmed that service quality creates patient loyalty with and without mediation of customer satisfaction. There many previous researches that investigate service quality, customer satisfaction, and customer loyalty, however, they only used multiple regression analysis or SEM. So, in this research, the researcher uses a combination of multiple regression analysis and SEM. The objectives of this research are: first, to see the impact of service quality on patient satisfaction; second, to see the impact of patient satisfaction on customer loyalty; third, to see the impact of service quality on patient loyalty. The respondents of this research are non-insurance outpatients of a private hospital in Tangerang, Indonesia by using a questioner. The data analysis methods of this research were multiple regression method for dimension of service quality toward satisfaction and Structural Equation Model (SEM) analysis for variable of service quality and customer satisfaction toward loyalty. The findings of this research show that: first, there is no direct impact of each dimensions of service quality on patient satisfaction, except assurance. It shows that the respondents don't distinguish all dimensions as a separate part where one dimension is prioritized than others; second, this research also finds that there is an impact of service quality on customer satisfaction improvement; third, there is direct impact of service quality on customer loyalty without mediation of customer satisfaction. Accordingly, it can be concluded that the customer loyalty is affected by customer satisfaction and service quality.
\end{abstract}

Keywords: service quality, customer satisfaction, customer loyalty

\section{Introduction}

Patient loyalty is built by patient experiences to the hospital depending on the level of experiences they have whether bad or good. Loyalty is a final stage of customer behavior. If customers are loyal, they will not shift to other products or services. In industrial business setting, maintaining loyalty is more difficult than finding new costumers. Cost for maintaining costumers are more expensive fifteen times than maintaining the existing customers (Jandahgi, 2011). Customer loyalty to product or service is very difficult to be shifted as long as such product or services remain superior than others. Only product or services offering same satisfaction with less expense can take the position.

A big challenge for a service company is providing and maintaining customer satisfaction. Cronin (2000) and Zafar, et al. (2012) state that the service quality affect customer satisfaction. Therefore, in order to provide customer satisfaction, the hospital should improve its service quality. It is also supported by Al-Rousan, et al. (2010) stating that a service company including hospital should strive to maintain excellent service quality that exceeds its competitor in order to get and maintain customer satisfaction. As a business actor or marketer, customer satisfaction should be maintained and improved because it gives feedback, namely customer willingness to make a reorder.

Having customers satisfied is not sufficient, they must be very satisfied because customer satisfaction leads to loyalty (Bowen and Chen, 2001). To survive in competitive service industry, a company should develop a new strategy to make its customers satisfied. Building customer loyalty is not an option in business, it is the one way to develop a sustainable competitive excellence. The linkage among service quality, customer satisfaction, and customer loyalty give creative ideas to improve service and accordingly to reach a competitive excellence in a service business (Siddiqi, 2011). Service quality is one of success factors that affect organization competitiveness. A company may differentiate itself from its competitors by providing a high quality service. Kumar, et al. (2010) finds that the service quality affects the customer satisfaction. This research is also supported by Naeem and Saif (2009) and Sanka (2012). According to Kettinger and Lee (1994), SERVQUAL instrument consists of five dimensions, namely: tangibles, reliability, responsiveness, assurance, and emphaty (Parasuraman, Berry, and Zeithaml, 1991). One of pivotal factors to make customer satisfied is a good 
relationship between employee and customer (Levesque and McDougall, 1996, in Siddiqi, 2011). An employee who promptly solves the problem may increase customer satisfaction. Through satisfaction, a company tries to create loyalty. It is better to maintain the existing customers before getting new customers (Walsh, et al. 2005). In addition, a service quality should be also improved because it is the root of loyalty so a good service will create good loyalty in customer's mind.

Previous researches on correlation among variables of service quality, customer satisfaction and customer loyalty only use a Structural Equation Model (SEM) method or multiple regression. However, the researcher uses a multiple regression analysis to examine the impact of dimension of service quality on customer satisfaction and a Structural Equation Model (SEM) analysis to examine the impact of service quality and customer satisfaction on customer loyalty. The findings show that: first, there is no direct impact of each dimensions of service quality on patient satisfaction, except assurance. It shows that the respondents don't distinguish all dimensions as a separate part where one dimension is prioritized than others; second, this research also finds that there is an impact of service quality on customer satisfaction improvement; third, there is direct impact of service quality on customer loyalty without mediation of customer satisfaction. Accordingly, it can be concluded that the customer loyalty is affected by customer satisfaction and service quality.

\section{Service Quality}

\section{Literature Review}

A qualified service is a service that economically profitable and procedurally easy and fun so it will create satisfaction. Satisfaction means a content feeling that arise after comparing the perception of results or performance of a service to the expectation. As stated by Chen (2009) that total satisfaction concept is a comprehensive evaluation of customers after they receive a previous service or experience. Edgar and Galia (2009) states that the quality contains matters that determine whether or not the service felt by customers conform to their expectation. Customer judges the quality of service based on their perception from technical outcomes. Parasuraman (1985) in Kheng, et al. (2010) states that service is a degree of difference arising from the process of service and interaction between service provider and customer. Parasuraman, et al. (1998) states that service quality is a multidimensional concept. Service quality dimensions are identified by a research conducted by Parasuraman, et al. known as SERVQUAL (Kotler and Keller, 2007) consisting of: first, tangibles, namely a physical appearance of facility, equipment, and various communication material.

Physical appearance, facilities, and infrastructure of the company and its surroundings are real evidences of service provided by a service provider; second, reliability, namely an ability to provide a service according to what company promise, trusted, accurate, consistent, and fit the expectation. Fit the customer satisfaction means a timely performance, zero-error service, sympathy, and high accuracy; third, responsiveness, namely a willingness of employee or employer to help customer and provide a service quickly and listen to and cope with customer's complaint, such as, a readiness of employee to serve customer, quick transaction, and customer's complaint handling; fourth, assurance, namely an ability of employee to raise customer belief and trust on promises offered, for example, an ability of employee to have informed knowledge of product, friendly, concern, and politeness in providing a service, providing security in utilizing service offered, and building customer trust to the company and fifth, empathy is a readiness of employee and employer to give customer deep and special concern in order to comprehend the customer's willingness, therefore, the company is expected to have specific understanding and knowledge about the costumers and their needs. This empathy dimension is a combination of: first, access including convenience to take benefit of service provided by the company; second, communication - an ability to give information to customer or to obtain customer's input; and third, comprehension about customers including an effort by the company to know and comprehend customers' needs and willingness.

\section{Customer Satisfaction}

The word 'satisfaction' originates from Latin language "satis" (sufficiently good, adequate) and "facio" (do or make). Simply, satisfaction is defined as an effort of fulfillment of something or making something adequate (Tjiptono, 2007). Howard and Sheth (1969) in Tjiptono (2007) state that customer satisfaction is a buyer's cognitive situation on gap between the results obtained and sacrifice made. Bitner and Zeithaml (1996) in Akbar and Parves (2009) stated that satisfaction is a customer's evaluation on product or service, whether or not the product or service meets their needs or expectations. Customer satisfaction plays an important role because there is a big difference in loyalty between customers who are just satisfied and those who are extremely satisfied (Lovelock and Wright, 2007). Ruswanti (2012) in her research concluded that customer satisfaction is a feeling resulting from an evaluation process about what is received on what to expect including the purchase decision of the goods itself, as well as the needs and desires associated with the purchase.

Customers have level of satisfaction and dissatisfaction after having or experiencing each service according to how far their expectation fulfilled or exceeded. Expectation is an internal standard used by 
customer to judge a quality of service experience (Lovelock and Wright, 2007). A company should maintain the quality of service provided to its customer. If the service quality received by customer is same or higher that what they perceive, the customer tends to buy the service again. However, if the perceived service is lower than the expected service, the customers will be disappointed and cause them stop their relation with the concerned company (Alma, 2005).

Alma (2005) states that dissatisfaction of customer with the service occurs due to the following causes: first, there is a gap between expectation and reality; second, poor service; third, bad behavior of personnel; fourth, unsupportive physical atmosphere and condition; fifth, too expensive cost, far distance; and sixth, promotion and advertisement are too excessive and different with the existing reality.

\section{Customer Loyalty}

Loyalty can be defined as fidelity. Loyalty arises without any duress, but awareness of past experience. An effort to create customer satisfaction tends to influence customer's behavior. While, concept of customer loyalty more stresses on buyer's behaviour. Loyalty is often stated by marketing experts and business. Loyalty is a difficult concept to discuss in daily context, but it is more difficult to analyze the meaning. Hasan (2008) explains the loyalty as follow: first, as a generic concept, brand loyalty shows a high tendency of customer to consistently buy a particular brand; second, as a behavioral concept, a re-ordering is often associated with brand loyalty. The difference is, if brand loyalty represents psychological commitment toward a particular brand, a reordering behavior means repurchasing of similar brand repeatedly; third, re-ordering is the result of success domination of product as one and only available alternative and continually run promotions to entice and persuade customers to buy the same product again.

Lovelock and Wright (2007), in business context, the term of loyalty used to illustrate the readiness of customers to continually subscribe to a company for long term, by buying and using its product and service repeatedly and exclusively, and voluntarily recommends the said company's product to their friends or colleagues. Although, loyalty is traditionally used to illustrate the loyalty and enthusiastic dedication to the country, dreams, or individual, Gramer and Brown (1983) in Utomo (2006) defines service loyalty as a degree to which a customer repeatedly uses a service from a service provider, possesses a positive disposition or tendency to the service provider and only considers to hire this service provided when he/she needs the service. Pearson (1996) in (Akbar and Parves, 2009: Ruswanti, 2012: Praja, Ruswanti and Hapsari (2016) defines a customer loyalty as a group of customers with supportive attitude toward the company, commitment to reorder the product or service from the company, and recommends the company's product or service to other persons. Dalton (2009) in Trasorras, et al. (2009) states that the customers will be loyal to those who help them to cope with the problem exceeding what they expect. Customer loyalty occurs when customer reorder the same product and ready to recommend the product to other customers without direct rewards and consequently such repeat order will impact on the measurable revenue (Al-Rousan, et al., 2010).

\section{Hypothesis Development}

A good service quality brings satisfaction to customers, and on contrary, a poor service quality brings dissatisfaction, not only to the customers who are at the location but also impact to others because a dissatisfied customer will tell his/her experience at least to 15 persons. The consequence is that potential customer will hire the competitor (Lupiyoadi and Hamdani, 2006). Service quality system improvement will be more effective for business continuity. Customer satisfaction is determined by the small gap between customers' expectations and the reality they experience when enjoy the service. SERVQUAL measures this gap by categorizing some main expectation dimensions in factorial form (Parasuraman, 1988). Sanka (2012) declares that there is a positive correlation between service quality dimensions and customer's satisfaction. Zafar, et al. (2012) also declare that there is a positive correlation between service quantity and customer's satisfaction. It is in line with Naeem and Saif (2009) who found that the customer satisfaction is the result of service quality. In their research, Wibowo, Ruswanti and Januarko (2013) concludes that the five dimensions of service quality will positively affect the customer's satisfaction.

Based on the above review, the writer proposes the following hypotheses: $\mathrm{H}_{1 \mathrm{a}}$ : The better tangibles, the higher satisfaction of patients, $\mathrm{H}_{1 \mathrm{~b}}$ : The higher reliability provided, the higher satisfaction of patients, $\mathrm{H}_{1 \mathrm{c}}$ : The better responsiveness, the higher satisfaction of patients, $\mathrm{H}_{1 \mathrm{~d}}$ : The better assurance provided, the higher satisfaction of patients, and $\mathrm{H}_{1 \mathrm{e}}$ : The higher empathy, the higher satisfaction of patients. The concepts of satisfaction and loyalty are interconnected. Customers who are satisfied with the service tend to enjoy the service repeatedly and even invite others to enjoy the service. Satisfied customers will invite others to become costumers of your company (Irianto, 2006). On the contrary, if customers are dissatisfied with the service, they are reluctant to promote the service to others. So that, improvement based on costumers' complaints will make customers become loyal to the company (Lupiyoadi and Hamdani, 2006). 
Bowen and Chen (2001) found that the customer satisfaction positively and significantly affect the customer's loyalty. This research is also in line with the research conducted by Molaee, et al. (2013); Molina, et al. (2007); Palitati (2007) and Anggraeni (2012) stated that the customer satisfaction positively affect the customer's loyalty. Singh (2006) stated that the satisfaction positively correlates with the willingness to make a repeat-order, and possibly recommends our product or service, - loyalty and profitability. Based on the above illustration, the writer proposes the following hypothesis: $\mathrm{H}_{2}$ : A good satisfaction degree will increase loyalty of patients.

Building customer loyalty is very difficult. If we have loyal customers, we have to maintain them with any strategies. One of them is by providing a good service quality. The better service quality, the more loyal customers will be. The company that successfully maintain its service quality will always be easy for them to maintain and even develop its business because its customers have been loyal, so the customers often reorder and willing to pay more (Johnson, 1997). Maintaining loyal customers are five times more difficult than acquiring new customers. The result of customers' judgment on service quality will create a particular customer loyalty pattern, namely from very loyal to very disloyal. Kotler (1994) states that a customer categorized as a loyal customer if he/she has consumption pattern to one service for any time and never move to other service, and it shows a very high level of loyalty. On the other side, customers are considered disloyal if they don't have loyalty to particular service. This type of customers has changing consumption pattern from one service to another. Direct qualified service can increase customer's loyalty.

A research conducted by Akbar and Parves (2009) shows there is positive correlation between service quality and customer loyalty and Kumar, et al. (2009) states that a good service quality will create high satisfaction and accordingly increase customer loyalty. To make a policy on improvement of customer loyalty, a service quality needs to be considered because this variable positively affects the customer loyalty (Yani, 2004). All service attributes positively affect customer satisfaction and the customer's satisfaction is directly correlated with customer loyalty (Siddiqi, 2011). Based on the above illustration, the writer proposes the following hypothesis: $\mathrm{H}_{3}$ : The better service quality, the higher loyalty degree of patients.

From the description mentioned above, the research model can be described as follows:

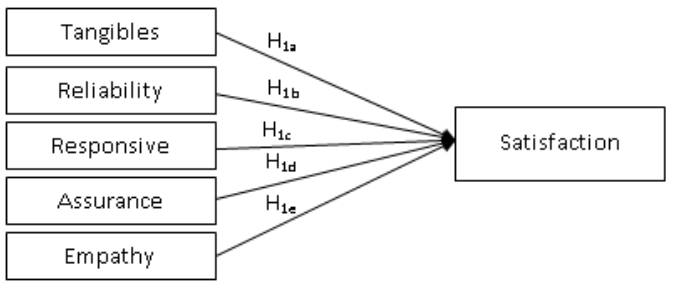

Figure1. First Model of Research

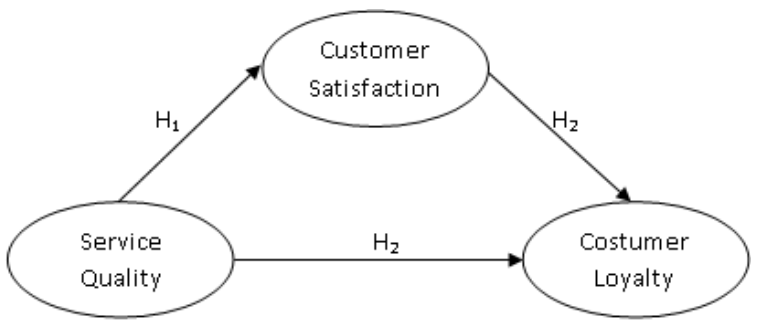

Figure2. Second Model of Research

\section{Research Method}

This research is conducted to non-insurance outpatients of private hospital in Tangerang, Indonesia. The aspects examined in this research include service quality and satisfaction toward loyalty. This research is conducted on March, 2017 using survey method. This research is a descriptive analysis with causality model. The data is collected by using questioners to the outpatients of Asshobirin Islam Hospital. This research uses non-saturated sampling with purposive sampling technique. The data is analyzed by a multiple regression statistic and SEM. The data is analyzed by statistic software. According to Hair, et al. (2008), the size of sample used is the number of indicators multiplied by five where the number of indicators in this research is 28 multiplied by five which equals to 140 , and this research uses 150 respondents and considered having fulfilled the requirement. The collected data is measured by Likert scale with one to four scales. The result of analysis is then interpreted and finally, conclusion and recommendations are made. 
Impact of Service Quality and Customer Satisfaction on Customer Loyalty: A Case Study in a Priv...

\section{Measurement}

In this research, there is one independent variable which is not affected by other variables in the model is represented by service causality construct. Intervening variable is an endogenous variable and also serve as an independent variable that affect other endogenous variables in a model represented by customer satisfaction construct and the dependent variable is affected by other variables in a model represented by customer loyalty construct. Measurement for variable of service quality use indicators from Parasuraman, et al. (1988) known as SERVQUAL (Kotler and Keller, 2007) consisting of: tangibles, reliability, responsiveness, assurance, and empathy, variable of patient's satisfaction adopted from Syah (2014) that adapts Crosby, et al. (1990); Kim and Cha (2002); Lin and Ding (2006) consisting of eight questions, variable of customer loyalty adopted from Syah (2014) that adapt Lin and Ding (2006), loyalty behavior is measured in three dimensions, namely: repeat patronage, switching behavior and Word of Mouth (WOM) recommendation.

This research uses confirmatory factor analysis by conducting validity test by considering scores of Kaiser-Meyer-Olkin measure of sampling (KMO) and measures of sampling adequacy (MSA). In this test, the value obtained must be higher 0.5 that means the factor analysis is correct and proper for use, and can be processed further (Malhotra, 2004). Service quality scale consists of 22 statements and 20 of them are valid statements (MSA > 0.5), the accepted statements are statements AN5 and EN4 because there two component matrix obtained when the data is inserted into data analysis, so that they are not included in the questioner of this research. There 3 statements for customer satisfaction scale and all is valid, there are 9 statements for customer loyalty scale and 5 of them are valid (MSA > 0.5), while the rejected statements are LY1, LY4, LY5 and LY6 because there are two component matrix obtained when inserted into data analysis so that they are not included in the questioner of this research. Reliability test with Alpha Cronbach $>0.6$ shows reliable (Anindita dan Hasyim, 2009), so it can be stated that indicators of service quality, patient's satisfaction and customer loyalty are reliable to collect data.

\section{Result Analysis}

\section{Result Analysis And Discussion}

This research uses multiple linear regression tests. The first hypothesis is to find out whether or not there is a significant impact of tangible, reliability, responsiveness, assurance, and empathy on customer's satisfaction. Before conducting a linear regression test to see the impact of service quality dimension on customer satisfaction, a classical assumption test is conducted. A classical assumption test consists of normality test, multicollinearity test, heteroscedasticity test and linearity test. Based on the normality test, it is found that residual significance value is 0.064 , exceeding the threshold $>0.05$, which means the tested data is normally distributed. Based on multicollinearity test, it is found that tolerance value for each variable is higher than 0.10 and CIF value is below 10.00 which means there is no multicollinearity in these variables. Based on heteroscedasticity, it is found that the significance value for each variable is higher than 0.05 to the absolute value of residue. In conclusion, it is feasible to conduct a multilinear regression test on independent variables. However, based on the normality test, it is found that significance value for variables of tangible, reliability and responsiveness is $>0.05$ and accordingly those variables are not liner with customer satisfaction. Consequently, those variables will not be tested. Only assurance and empathy variables will be examined by a linear regression test. Only assurance and empathy variables with significance value of $<0.05$ will be taken for subsequent steps because they are significantly linearly correlated with customer satisfaction.

Based on the linear regression test, a null hypothesis is rejected if the significance value is below 0.05 . This linear regression test model produces F value of 20,387 exceeding F-table value of 2.2141 with significance value below $<0.05$ and R2 0.217 . It means the null hypothesis is rejected and it confirms that there is an impact of assurance and empathy on customer satisfaction. This model explains that $21.7 \%$ variation of existing data and the remaining is determined by other variables not detected in this research. Hypothesis test by variable is consulted with the following hypothesis: $\mathrm{H}_{0 \mathrm{~d}}$ : quality of assurance dimension doesn't affect customer satisfaction abd $\mathrm{H}_{0 \mathrm{e}}$ : quality of empathy dimension doesn't affect customer satisfaction.

Based on the linear regression test, the significance value and beta value are shown on the following table:

Table 1 Summary of linear regression test results

\begin{tabular}{|l|l|l|l|l|}
\hline Variable & B Value & Significance & Parameter & Decision \\
\hline Assurance & 0.424 & 0.000 & $<0.05$ & $\mathrm{H}_{0 \mathrm{~d}}$ is rejected \\
\hline Empathy & -0.065 & 0.764 & $>0.05$ & $\mathrm{H}_{0 \mathrm{e}}$ is accepted \\
\hline
\end{tabular}

The above table shows partially significant value of each correlation path, that only assurance dimension rejects $\mathrm{H}_{0}$ which means only assurance dimension affects customer satisfaction.

The subsequent hypothesis test is a multilinear regression test with path analysis by using a statistic software in order to see the impact of service quality and customer satisfaction on customer loyalty. However, before conducting such hypothesis test, variable dimensionality test is conducted. The first test is for service 
quality dimension. At this stage, all items is treated same, combined with latent (factor) variable of service quality. The result of dimensionality test for service quality constructs shows the KMO value is 0.745 with significance value of 0.000 which means they are valid. Based on the result of dimensionality test, it is found that DT4 and JM4 have factor variable less than 0.3. Therefore, the modeling will exclude them. The second test is conducted to customer satisfaction showing the KMO value is 0.725 with significance value of 0.000 , and all items has loading factor value above 0.3 , which means testing for this factor can be conducted. The third test is conducted to customer loyalty showing the KMO value of 0.795 with significance value of 0.000 which means testing for this factor can be conducted. Further, the three variables will be tested to see the impact of service quality and customer satisfaction on customer loyalty. The hypothesis tested is as follow: $\mathrm{H}_{1}$ : The impact of service quality on satisfaction is found, $\mathrm{H}_{2}$ : The impact of satisfaction on customer loyalty is found and $\mathrm{H}_{3}$ : The direct impact of service quality on customer loyalty is found.

Based on SEM analysis result, it is found that the service quality (X1) and satisfaction (X2) together significantly affect customer loyalty $(\mathrm{Y})$ at $\mathrm{P}<0.05$ with notation of $\mathrm{Y}=0.295 \mathrm{X} 1+0.427 \mathrm{X} 2$. In addition, such testing also confirms that service quality (X1) may significantly predict satisfaction (X2) at $\mathrm{P}<0.05$ with notation of $\mathrm{X} 2=0.575 \mathrm{X} 1$, so that both condition produce mediation effect, where the service quality affect loyalty on two paths, direct effect path $0.602 \mathrm{X} 1$ and indirect effect $(\mathrm{Y}=$ direct effect $\mathrm{X} 1+$ indirect effect $\mathrm{X} 1)$ if notated $\mathrm{Y}=0.295 \mathrm{X} 1+(0.575 \times 0.427) \mathrm{X} 1=0.295 \mathrm{X} 1+0.245 \mathrm{X} 1$. The interesting finding shows that customer loyalty is highly affected by direct effect than indirect effect (through satisfaction). It means that to be loyal, the customer should not get through satisfaction appreciation to the service quality he/she get, but through other factors. For more detail, please see the following diagram.

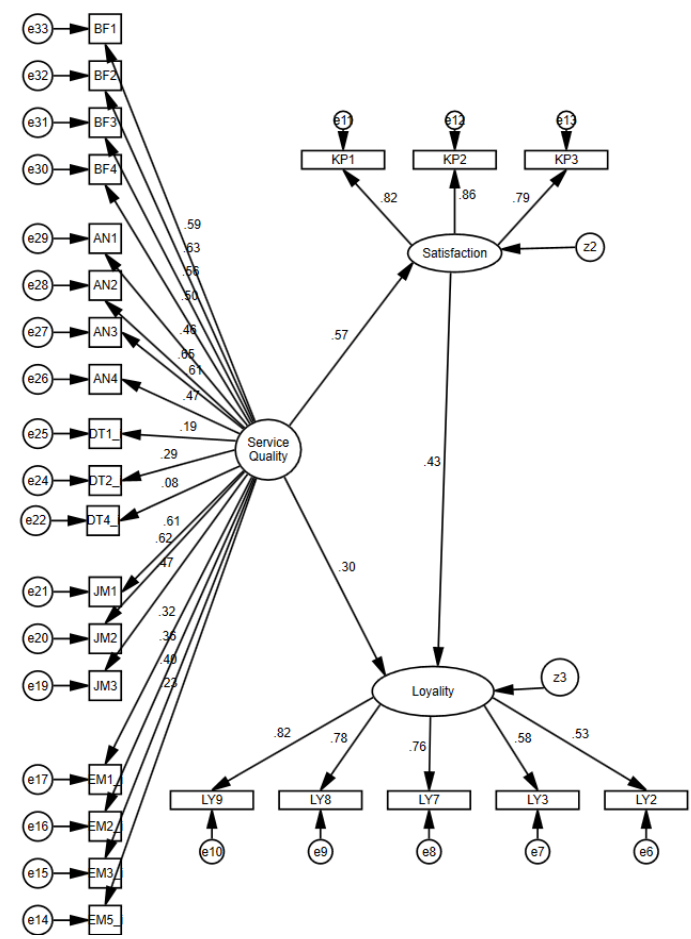

Figure 3 Diagram of Path of Service Quality, Satisfaction and Customer Loyalty

Based on the test result, it is found that service quality and satisfaction together significantly affect customer loyalty with notation Loyalty $=0.295$ Service Quality +0.427 Satisfaction. It shows that there is a direct impact of service quality on customer loyalty, and there is a direct impact of customer satisfaction on customer loyalty.

From the above model, we also find that the service quality may predict customer satisfaction with notation Satisfaction $=0.575$ Service Quality. It shows the interaction of impact of service quality on loyalty, where there is direct impact of service quality of 0.295 and a direct impact through mediation of customer satisfaction of $0,575 \mathrm{x} 0.427=0.245$. Simply, the notation shows that the service quality directly affect and indirectly (via mediator) affect customer satisfaction of Loyalty $=0.295$ Service Quality (direct affect) +0.245 Service Quality (indirect affect through satisfaction). The following is the result of hypothesis tests: 
Impact of Service Quality and Customer Satisfaction on Customer Loyalty: A Case Study in a Priv...

Table 4. Structural Relationship Test Result

\begin{tabular}{|l|l|l|l|}
\hline Hypothesis & \multicolumn{1}{|c|}{ Hypothesis Statement } & Sig. Value & \multicolumn{1}{|c|}{ Conclusion } \\
\hline $\mathrm{H}_{1 \mathrm{a}}$ & $\begin{array}{l}\text { The better tangibles, the higher satisfaction of } \\
\text { patients. }\end{array}$ & $\begin{array}{l}\mathrm{H}_{1 \mathrm{a}} \text { is not tested bacause the significance value } \\
\text { on linerity test is }>0.05\end{array}$ \\
\hline $\mathrm{H}_{1 \mathrm{~b}}$ & $\begin{array}{l}\text { The more reliability provided, the higher } \\
\text { satisfaction of patients. }\end{array}$ & $\begin{array}{l}\mathrm{H}_{1 \mathrm{~b}} \text { is not tested bacause the significance value } \\
\text { on linerity test is }>0.05\end{array}$ \\
\hline $\mathrm{H}_{1 \mathrm{c}}$ & $\begin{array}{l}\text { The better responsiveness, the higher } \\
\text { satisfaction of patients. }\end{array}$ & $\begin{array}{l}\mathrm{H}_{1 \mathrm{c}} \text { is not tested bacause the significance value } \\
\text { on linerity test is }>0.05\end{array}$ \\
\hline $\mathrm{H}_{1 \mathrm{~d}}$ & $\begin{array}{l}\text { The better assurance provided, the higher } \\
\text { satisfaction of patients. }\end{array}$ & 0.000 & Data supports the hypothesis \\
\hline $\mathrm{H}_{1 \mathrm{e}}$ & $\begin{array}{l}\text { The higher empathy, the higher satisfaction of } \\
\text { patients. }\end{array}$ & 0.764 & Data supports the hypothesis \\
\hline $\mathrm{H}_{1}$ & $\begin{array}{l}\text { The better service quality, the higher loyalty } \\
\text { degree of patients. }\end{array}$ & $\begin{array}{l}\text { A good satisfaction degree will increase loyalty } \\
\text { of patients. }\end{array}$ & 0.000 \\
\hline $\mathrm{H}_{2}$ & $\begin{array}{l}\text { The better service quality, the higher loyalty } \\
\text { degree of patients. }\end{array}$ & 0.000 & Data supports the hypothesis \\
\hline $\mathrm{H}_{3}$ & Data supports the hypothesis \\
\hline
\end{tabular}

\section{Discussion}

Hypothesis $1 \mathrm{a}, 1 \mathrm{~b}$ and $1 \mathrm{c}$ was not conducted because based on linear test, it is found that there is no linear correlation between tangible, reliability, and responsiveness toward patient satisfaction. It is shown by significance value of tangible to patient satisfaction, which is $0.620(>0.05)$, reliability to patient satisfaction is $0.643(>0.05)$ and responsiveness to patient satisfaction is $0.269(>0.05)$. The result of hypothesis $1 \mathrm{~d}$ test shows that the analysis result support $\mathrm{H}_{1 \mathrm{~d}}$ namely the better assurance provided, the higher degree of patient satisfaction will be. It is shown by the significance value of assurance to customer satisfaction, namely 0.000 $(<0.05)$. A research conducted by Yuliarmi (2007), Minh, et al. (2015) and Bharwana, et al. (2013) found similar result, that there are positive and significant impact of assurance provided on customer satisfaction.

The result of hypothesis 1e $\left(\mathrm{H}_{1 \mathrm{e}}\right)$ test shows that the analysis result doesn't support $\mathrm{H}_{1 \mathrm{e}}$ namely the better assurance provided, the higher degree of patient satisfaction will be. It is shown that the significance value of empathy to customer satisfaction is $0.394(>0.05)$. It shows that the impact of empathy on customer satisfaction is not sufficient. Accordingly, the empathy doesn't significantly affect customer satisfaction.

It is interesting to note that empathy has no influence on patient satisfaction because intuitively it has. This variable still needs to be explored. Based on the data, it is shown that the frequency data of empathy is normally distributed, in reference to Komolgorof-Smirnov test. The table below shows the value is -.354 (standard value for Skewness is +1.96 ) which means the data tends to left confirming that the respondents' responses are negative. To see distribution of response, the Kurtosis is 0.229 of mesokurtic standard +1.96 showing the data is platykurtic which means variability to complete the questioners is high.

According to the writer, there are three reasons why empathy has no influence on patient satisfaction. First, from the context of respondents, the patients have no sufficient emphatic sensitivity when they are asked to give their opinions, so they complete the questioners without referring to what they feel. It shows that the SERVQUAL instrument that stresses on the process of service delivery need to be reexamined, especially for health industry, where the customers have complaint on the service provided. This concept is criticized by Blake (1994) stating that the customer evaluates the service from one moment of truth (MOT) to other MOT at different psychological state. MOT at hospital is related to health problems with recovery expectation. It is different with expectation to get a good service because we sometimes hold our expectation to conformity (consuming drug, for example) because we only need recovery. Second, from the context of hospital, the private hospital gets its health facilities not only from its patients as private hospitals but also from government aid. the facilities from non-public insurance, ministry of health aid, and other funding interventions bring additional tasks for the hospital where it not only think its patients treatment, but also donor's expectation. The position of patient, in this case, is similar with the position of hospital. In brief, when patients have poor service, they will not blame the hospital but the government that give little support and others. It leads to expectation bias.

Third, from the statements of questioner, the placement of polarity statements are composed in positive statement especially for constructs of evidence, reliability, and assurance, while for constructs of responsiveness and empathy are composed in negative statement, so they need to be inversed. The difference of statement frame based on dimensions produce risks including different mental state and incomparable among dimensions. The result will be different if inverse statement technique is distributed to all dimensions so we can conduct a comparative test with ANOVA to see the different between positive statements and negative statements.

The result of hypothesis 1e (H1e) test is also found in a research conducted by Yuliarmi (2007) and Bharwana, et al. (2013) stating that there is no impact of empathy on customer satisfaction. The finding is contrary with the 
finding of research conducted by Minh, et al. (2015) stating that there is an impact of empathy on customer satisfaction. The result of hypothesis $1\left(\mathrm{H}_{1}\right)$ test shows that the analysis result supports $\mathrm{H}_{1}$, namely a good service quality can increase patient satisfaction. It is shown by beta value of $1.780(\mathrm{p}<.001)$. This finding supports the finding of previous research conducted by Jahansashi, et al. (2011) stating that there is a high positive correlation between customer service construct and product quality to consumer satisfaction. Liao (2012) in his research on steel industry in Taiwan tries to explore the causal correlation among service quality, customer satisfaction, and customer loyalty in steel industry. The research finds that service quality directly create customer satisfaction as found by Yuliarmi (2007), Minh, et al. (2015), Praja, et al. (2016) and Bharwana, et al. (2013). Hafeez and Muhammad (2012) also conclude that customer satisfaction is a pivotal factor in increasing a service quality so that the company should be focused to improve its service quality in order to increase customer satisfaction and finally bring loyalty to the customer. The same finding is also found by Sabir et al. (2013). The result of hypothesis $2\left(\mathrm{H}_{2}\right)$ test shows that the analysis result supports $\mathrm{H}_{2}$, namely customer satisfaction can increase patient loyalty. It is shown by beta value of $0.282(\mathrm{P}<0.01)$. This finding reinforces the previous finding of research conducted by Vuuren, et al. (2012). In their research on Optometric business, it is stated that the customer satisfaction has highest correlation with customer loyalty although other independent variables also significantly affect the customer loyalty. Sabir, et al. (2013) also conduct a research on telecommunication sector in Punjab, India, stating that customer satisfaction and loyalty program have significant impact on customer loyalty. The same is also stated by Yasa and Dewi (2014), ), Praja, et al. (2016) and Nejad, et al. (2014). This hypothesis is contrary with the research conducted by Akbar and Parves (2009) stating that customer satisfaction plays its role as an important mediator between service quality and customer loyalty, but the customer satisfaction can't reach the goal to create loyal customers basis. The analysis result supports hypothesis $3\left(\mathrm{H}_{3}\right)$, namely service quality may directly increase customer loyalty. It is shown by beta value of $0.602(\mathrm{p}<0.01)$. The finding is in line with finding of previous research conducted by Setiawan and Ukudi (2007) stating that loyalty may directly increase customer trust and commitment and service quality may increase loyalty because it positively and significantly affect customer trust and commitment and accordingly affect their loyalty. Hafeez and Muhammad (2012) in their research state that there is a positive and significant correlation between service quality and customer loyalty as found by Wantara (2015) and ), Praja, et al. (2016). This finding is contrary to the finding of research conducted by Aryani and Rosinata (2010) stating that the five determinants of service quality positively and significantly affect service quality but there is no correlation between service quality and customer loyalty. Liao (2012) also finds in his research that service quality and customer satisfaction in steel industry directly correlate with customer loyalty but service quality has no direct impact on customer loyalty but mediated by customer satisfaction.

\section{Managerial Implications}

Quality of service with all dimensions can have a direct and indirect effect on patient loyalty. This means that all parts of the hospital can affect whether patients will return to treatment or not when they need health services. The managerial implications that can be suggested to improve patient satisfaction are the hospitals focus on improving the quality of service, especially the patient's guarantee. This can be done with several dimensions: first, by consistently communicating how the hospital supports the doctor by conducting regular training. This training is conducted so that doctors get a refresher and reorientation to the purpose of the profession and the importance of ensuring quality service to patients. Information on service training activities for the physician needs to be installed in a visible place by the patient so that the patient is aware of the hospital's support for the doctor is very high to improve their recovery guarantee; Secondly, to update the medical device carefully and attentively to ensure the condition of the medical device can be used when necessary and the hospital should communicate the cycle of replacement of the medical device to the patient with a brochure or pamphlet medium so that the patient knows the seriousness of the hospital in taking care of the patient's service; And third, how the hospital's service management system is designed to optimally improve the patient's cure guarantee. The next managerial implications that a hospital needs to do is maping out loyal patients or who, when ill, always come to the hospital and patients who are frequently hospitalized. For a loyal patients focused on how to optimize the patient's medical information to improve service, and for hospitalfrequent patients attention is focused on acquiring information both in the evaluation of the hospitals they were visited and their medical records to improve quality. Interventions applied to this type of patient were decided on the basis of the uniformity of the patient's frequent switching behavior, with an indicator of the success of which the patient could be converted, meaning that at first he often moved to be loyal. With this approach, hospitals can monitor the patient's increase by the extent to which the addition of converted loyal patients.

Access to hospitals needs to be improved such as opening alternative roads to hospitals, access in and out, adding parking area, controlling the spot of interest around the hospital to be recommended as well, There should be an effort to increase the presence visibility by adding anchor for more Attractive, hospitals also need to consider adding new services such as the opening of fast laboratory services, provision of push through 
drugstore services, home delivery of drugs through third party services or courier. Hospitals also need to standardize the waiting time of patients in the waiting room before getting needed services, especially in the registration section, polyclinics, and pharmacies. Intensification of supervision in this regard will be very beneficial for patient loyalty. Hospitals also need to consider to provide applications on mobile devices so that without the need for two-way communication then the patient can get information quickly. Based on the above condition, it is important for the hospital management to set and specify a standardization of proactive service quality. It means that management, to make a decision, not only depends on customer input, but also directly examines the impact of infrastructure improvement, communication method, and qualified service dimensions that will directly increase the number of customer. The quality standardization and the increasing number of customers become main priority for evaluation than customer complaint.

\section{Conclusion}

Based on the above discussion, the three main points are drawn as conclusion, they are: first, only assurance that may predict customer satisfaction. It shows that the customers don't have definitive discrimination to determine whether they are satisfied or not with the service provided by the Islamic Hospital of Asshobirin; second, Satisfaction, it is found that there is an impact of service quality on customer satisfaction amounting to $1.780, \mathrm{p}<.001$, and the impact of satisfaction of loyalty amounting to $0.281, \mathrm{p}<.001$. The interesting one is that there is a direct impact of service quality on loyalty amounting to $0.602, p<.001$. If we see the beta value, the service quality, without an appreciation of customer satisfaction may directly affect customer loyalty; and third, Service quality, it affects customer loyalty to visit the hospital again, although they don't have satisfaction to the service provided.

\section{Limitation of Research}

\section{Limitations Of Research And Recommendations}

Limitation of this research is useful for the following research. This research uses questioner as a measurement tools for the sake of efficient of time and resources. However, questioner has its own limitation such as bias in answering the questions. There is a possibility that respondents didn't answer the question truthfully or they only give their answers based on the expected ideal condition - not the real one. It may cause the measurement used don't represent the variables in real setting. In addition, the limited number of samples and variables that affect service quality and satisfaction toward customer loyalty, and the limited analysis therefrom make the researcher can't examine other factors that affect customer loyalty.

\section{Recommendations for Future Research}

This research is very limited because it only examines the service quality and satisfaction toward customer loyalty. So, for the following research, it is suggested to add other variables that affect customer loyalty. It is also expected that the following research will be conducted at other service company, such as bank, hotel, notary office and others by using varied data in order to get more objective result for wider scope.

\section{References}

[1] Akbar, M.M. \& Parvez, N. (2009). Impact of Services Quality, Trust, and Customer Satisfaction on Customer Loyalty, ABAC Journal, Vol. 29, No. 1, pp. 24-38.

[2] Alma, B. (2005). Manajemen Pemasaran dan Pemasaran Jasa. Bandung: Alfabeta.

[3] Al-Rousan., Ramzi, M. \& Mohamed, B. (2010). Customer Loyalty and the Impacts of Service Quality: The Case of Five Star Hotels in Jordan International, Journal of Business and Economic Sciences, Vol. 5, pp. 202-208.

[4] Anggraeni, S. (2012). Pengaruh E-Service Quality terhadap Kepuasan dan Loyalitas Pelanggan (Kasus Pada Pengguna Internet Banking di Commonwealth Bank Cabang Seminyak Bali), Tesis, Program Studi Magister Manajemen Universitas Udayana, Denpasar.

[5] Anindita, R. \& Hasyim. (2009). Prinsip-Prinsip dasar Metode Dalam Pemasaran. Jakarta: UEU - Universitas

[6] Aryani, R. \& Rosinata, F. (2010). Pengaruh Kualitas Pelayanan terhadap Kepuasan Pelanggan dalam membentuk Loyalitas Pelanggan. Jurnal Ilmu Administrasi dan Organisasi, Bisnis \& Birokrasi.Vol. 17 Nomor 2.Hal.114-126.

[7] Bharwana, T.K., Bashir, M. \& Mohsin, M. (2013). "Service Quality and Customer Satisfaction: A Case Study of Hotel Industry in Vietnam", International Journal of Scientific and Research Publications, Volume 3, Issue 5, May 2013.

[8] Blake, F. (1994). SERVQUAL: review, critique, research agenda. European Journal of Marketing 30,1.

[9] Bowen, John T \& Chen, S.L. (2001). The Relationship Between Customer Loyalty and Customer Satisfaction, International Journal of Contemporary Hospitality Management, Vol. 13, No. 5, pp. 213-217.

[10] Chen. (2009). Identification of Escherichia coli enterotoxin inhibitors from traditional medicinal herbs byin silico, in vitro, and in vivo analyses. Journal of Ethnopharmacology. 121: 372-378

[11] Cronin, J. J., Michael Jr, K.B. \& Hult, G.T.M. (2000). Assessing The Effects of Quality, Value, and Customer Satisfaction on Consumer Behavioral Intentions in Service Environments, Journal of Retailing, Vol. 76, No. 2, pp. $193-218$.

[12] Edgar, M \& Galia, F. (2009). Why and How Service Quality Perceptions Impact Consumer Responses, Journal of Managing Service Quality, Vol. 19, No. 4, pp. 474-485.

[13] Hair, J. F., Black, W. C., \& Babin, B. J. (2013). Multivariate Data Analysis (7 ed.). New York: Pearson.

[14] Hafeez, S. \& Bakhtiar, M. (2012). The Impact Service Quality, Cutomer Satisfaction and Loyalty Program on Customer's Loyalty: Evidence from BankingSector of Pakistan, International Journal of Business dan Social Science, Vol. 3 No. 16, August, 2012. 
[15] Hasan, A. (2008). Marketing. Yogyakarta, Media Utama.

[16] Irianto, A. (2006). Statistik Konsep Dasar dan Aplikasinya. Jakarta: Prenada Media.

[17] Jahanshahi, A.A., Gashti. M.A.H., Mirdamadi, S.A., Nawaser, K., \& Khaksar,.S.M.S. (2011).Study the effects of Customer Service and Product Quality on Customer Satisfaction and Loyalty. International Journal of Humanities and Social Science. Vol 1 No. 7.

[18] Jandahgi. (2011). Studying the effect of brand Loyalty on Customer Service Asian Insurance Company. Journal Business and Management.

[19] Johnson, D.M., (1997). Customer orientation and market action. Englewood Cliffs, New Jersey: Prentice hall international inc.

[20] Kheng, L.L., Mahamad, O., Ramayah, T., \& Mosahab, R. (2010). The Impact of Service Quality on Customer Loyalty: A Study of Banks in Penang, Malaysia, International Journal of Marketing Studies, Vol. 2, No. 2, pp. 57- 66.

[21] Kotler, P. (1994). Marketing Management: Analysis, Planing, Implementation and Control, (8nd) ed, International Edition, Englewood Cliffs, New Jersey: Prentice Hall Inc,

[22] Kotler, P. \& Keller, K.L. (2007).Manajemen Pemasaran. Jilid 1 dan 2. Jakarta:PT Indeks.

[23] Kumar, M., Kee, F. T. \& Manshor, A. T. (2009). Determining the Relative Importance of Critical Factors in Delivering Service Quality of Banks: an Application of Dominance Analysis in SERVQUAL Model, ManagingService Quality, Vol. 19, No. 2, pp. 211228.

[24] Kumar, S.A., Mani, B. T., Mahalingam, S., \& Vanjikovan, M. (2010). Influence of Service Quality on Attitudinal Loyalty in Private Retail Banking: an Empirical Study, IUP Journal of Management Research, Vol. 9, No. 4, pp.21-38.

[25] Liao, K.H. (2012). Service Quality and Customer Satisfaction: Direct and Indirect Effect in B2B Customer Loyalty Framewoek, The Journal of Global Business Management Volume 8 No. 1.

[26] Lovelock, C.H \& Wright, L.K. (2007). Manajemen Pemasaran Jasa. Edisi Bahasa Indonesia.Jakarta: PT Indeks.

[27] Lupiyoadi, Hamdani. (2006). Manajemen Pemasaran Jasa, Edisi Kedua. Jakarta : Penerbit Salemba Empat

[28] Malhotra, N. K. (2009). Riset Pemasaran. Edisi Keempat. Jakarta: PT Indeks. 100

[29] Minh, N.H., Ha, N.T, Anh, P.C., \& Matsui, Y. (2015). "Service Quality and Customer Satisfaction: A Case Study of Hotel Industry in Vietnam", Asian Social Science, Vol. 11, No. 10.

[30] Molaee, M., Ansari, \& Telmouri, H. (2011). Analizing The Impact of Service Quality Dimensions on Customer Satisfaction and Loyalty in The Banking Industry of Iran, International Journal of Academic Research in Accounting, Finance and Management Sciences, Vol. 13, No. 3, pp. 5-13.

[31] Molina, A., Consuegra, D., \& Esteban, A. (2007). Relation Benefit and Customer Satisfaction in Retail Banking, International Journal of Bank Marketing, Vol. 25, No. 4, pp. 253-270.

[32] Naeem, H., \& Saif, I. (2009). Service Quality and Its Impact on Customer Satisfaction: An Empirical Evidence from the Pakistani Banking Sector, The International Business and Economics Research Journal, Vol. 8, No. 12, pp. 99-104.

[33] Nejad, LR., FiroozbABC, Z., \& Taghipoor , A. (2014). Service Quality, Relationship Quality and Customer Loyalty (Case Study: Banking Industry in Iran). Open Journal of Social Science, 262-268.

[34] Palitati, A. (2007). Pengaruh Nilai Pelanggan, Kepuasan Terhadap Loyalitas Nasabah Tabungan Perbankan di Sulawesi Selatan, Journal Manajemen dan Kewirausahaan, Vol. 9, No. 1, pp. 73-81.

[35] Parasuraman, A., Zeithaml, V.A., \& Berry, L. (1988). SERQUAL: Multiple-item scale for Measuring consumer Perceptions of Service Quality, Journal ofRetailing, Vol. 64, No. 1, pp. 12-40.

[36] Praja, A.K.A., Ruswanti, E. \& Hapsari, N.P. (2016). The Six Dimension Service of Quality on Loyalty mediated Student Satisfaction Batavia University. Ijaber, Vol. 14, No. 12, (2016): 8753-8766.

[37] Ruswanti, E. (2012). Pengaruh Service Quality dan Customer Satisfaction terhadap Customer Loyalty. Widya Tahun 29 Nomor 318 Maret 2012. pp. 49-54.

[38] Sabir, R.I., Irfan, M., Sarwar, M.A., Sarwar, B., \& Akhtar, N. (2013). The Impact Service Quality, Cutomer Satisfaction and Loyalty Program on Customer's Loyalty: an Evidence from Telecomunication Sector. Journal of Asian Business Strategy, 3(11) 2013: 306314.

[39] Sanka, M.S. (2012). Bank Service Quality, Customer Satisfaction and Loyalty in Ethiopian Banking Sector, Journal of Business Administration andManagement Sciences Research, Vol. 1, No. 1, pp. 001-009.

[40] Setiawan, M.B. \& Ukudi. (2007). Pengaru Kualitas Pelayanan, Kepercayaan dan Komitmen terhadap Loyalitas Nasabah (Studi pada PD. BPR Bank Pasar Kendal). Jurnal Bisnis dan ekonomi (JBE), Bol. 14 No. 2. Hal 215-227

[41] Siddiqi, K.O. (2011). Between Service Quality Attributes, Customer Satisfaction and Customer Loyalty in the Retail Banking Sector in Bangladesh, International Journal of Business and Management, Vol. 6, No. 3, pp. 12 - 36.

[42] Singh, H. (2006). The Importance of Customer Satisfaction in Relation to Customer Loyalty and Retention, Asia Pacific University College of Technology \& Innovation Technology Park Malaysia, UCTI Working Paper, pp. 1-6.

[43] Syah, Tantri Yanuar Rahmat . (2014). Provider's participant fasility as customer loyalty creator, mediated by relationship quality, and moderated by implicit self theorist. University of Indonesia

[44] Tjiptono, F. (2007). Manajemen Jasa. Edisi Keempat. Yogyakarta: Andi Offet. Undang-undang No.10 Tahun 1998 Tentang Perubahan atas Undang-undang No.7 Tahun 1992 tentang Perbankan.

[45] Trasorras. R., Weinstein, A., \& Abrat, R. (2009). Value, Satisfaction, Loyalty and Retention in Professional Services, Marketing Intelligence \& Planning, Vol. 27, No. 5, pp. 615-632.

[46] Utomo, Priyanto Doyo. (2006). Analisis Terhadap Faktor-Faktor Yang Mempengaruhi Loyalitas Konsumen Pada Operator Telepon Seluler. Thesis: Universitas Gadjah Mada.

[47] Vuuren, T.V., Lombard, M.R., \& Tonder, E.V. (2012). Customer Satisfaction, trust and commitment as predictors of cutomers loyalty within an optometric practice environment. Southern African Review. Volumen 16 No. 3.

[48] Walsh, G., Groth, M., \& Wiedmann, K.P. (2005). An Examination of Consumers' Motives to Switch Energy Suppliers, Journal of Marketing Management, Vol. 21, pp. 421-440.

[49] Wantara, P. (2015). The Relatiship among Service Quality, Customer Satisfaction, and Customer Loyalty in Library Servces, International Journal of Economic and Financial Issues, Vol. 5.

[50] Wibowo, S.A., Ruswanti, E. \& Januarko, U. (2013). Pengaruh Persepsi Kualitas Pelayanan terhadap Niat Pembelian Ulang pada Toko Buku Gramedia Yogyakarta. Jurnal Ekonomi. Volume 4 No. 1.

[51] Yani, Elfida. (2004). Pengaruh Produk terhadap Loyalitas Nasabah Bank Sumut Medan. USU Repository.

[52] Yasa, N.N.K. \& Dewi, G.A.P.R.K. (2014). Pengaruh Kualitas Pelayanan terhadap kepuasan dan Loyalitas Nasabah PY BPR Hoki di Kabupaten Tabanan. E-Jurnal Ekonomi dan Bisnis Universitas Udayana 3.5 : 257-275

[53] Yuliarni, N.N. dan Riyasa, P. (2007). Analisis Faktor-Faktor yang mempengaruhi Kepuasan Pelanggan terhadap Pelayanan PDAM Kota Denpasar. Buletin Studi Ekonomi. Volume 12 Nomor 1 Tahun 2007.

Researcher: 
1. Jamaluddin, MM. in Assosiation Magister Management Esa Unggul University of Jakarta Indonesia

2. Dr Endang Ruswanti, SE., MM. is assigned to the faculty Economic Bussines of Higher Education Esa Unggul University of Jakarta Indonesia, has been teaching for 30 years. Active as a researcher of consumer behavior and marketing management 